\title{
Anxiolytic-like effect of Urena lobata (L.) in swiss albino mice
}

\author{
Muhammad Torequl Islam', Thoufiqul Alam Riaz², Seyed Abdulmajid Ayatollahi ${ }^{3,4}$ and Javad Sharifi-Rad ${ }^{3,5^{*}}$
}

\begin{abstract}
Anxiety disorders are general and psychological problems that are also linked to symptoms of depression. This study aimed to investigate the anxiolytic-like effects of Urena lobata L. (MEUL) methanolic extract in different behavioral paradigms in Swiss albino mice. For this, after an oral acute toxicity study, adult male mice were treated with MEUL (250 and $500 \mathrm{mg} / \mathrm{kg}$, p.o.) and/or diazepam ( $2 \mathrm{mg} / \mathrm{kg}$, i.p.), and subjected to a number of behavioral studies. In the open-field test, the number of square field cross, grooming, and rearing, was counted, while in the light/dark and swing test, the time spent in the dark portion and number of swings was calculated, respectively. Additionally, the phytochemical analysis was also done. Results reveal that the MEUL possesses alkaloids, glycosides, flavonoids, phenols, saponins, terpenes (including triterpenes), gums, and reducing sugars. MEUL showed a significant $(p<0.05)$ anxiolytic-like effect in experimental animals, where it's dose-dependently modulated the test parameters in an open-field test. The MEUL also increased the light residence time and the number of swings in a dose-dependent manner. A dose of $500 \mathrm{mg} / \mathrm{kg}$ of MEUL caused the highest calming effect when combined with the experimental animals' diazepam group. Taken together, findings expand an understanding of the impact of $U$. lobata on the central nervous system and show that this plant may be useful for the treatment of disorders associated with anxiety.
\end{abstract}

Keywords: Urena lobata, Anxiety, Mus musculus, Behavioral study

\section{Introduction}

Herbal medicines (also called green medicinal products) are relatively healthy and effective paradigms of health care. In the last few years, traditional herbal medicine has drawn researchers' attention to the world because of its several pharmacological activities, economic viability, and fewer side effects [6]. The use of herbal medicine to treat many psychiatric disorders has become more established, as traditional pharmacotherapy is considered safer support [32].

Compare with other disease areas, developing a new drug for the central nervous system (CNS) is a unique challenge [7]. Drugs acting on the CNS, such as CNS depressants including barbiturates and benzodiazepines

\footnotetext{
* Correspondence: javad.sharifirad@gmail.com

${ }^{3}$ Phytochemistry Research Center, Shahid Beheshti University of Medical Sciences, Tehran, Iran

${ }^{5}$ Facultad de Medicina, Universidad del Azuay, Cuenca, Ecuador

Full list of author information is available at the end of the article
}

(BDZs), among others, exert their effect through interaction with the postsynaptic gamma-aminobutyric acid (GABA) receptor [13]. These drugs are not so safe, and they are toxic. For example, benzodiazepines and Zdrugs (e.g., zopiclone, zolpidem) are evident to cause cognitive problems at low doses [34]. These drugs also build psychological and physiological dependence in patients $[9,16]$. BDZs are widely used as CNS depressants, which have been reported to develop tolerance and physical dependence [12, 33], making us think about new safer CNS depressants. Drugs from natural sources may be a good solution; for example, Luvah and coworkers introduced Ajuga remota (Lamiaceae) components with anxiolytic-like effects [21].

Similarly, Schier and colleagues' research suggested that cannabidiol (CBD) exhibits an anti-anxiety and antidepressant effects in animal models. Also, experiments with $\mathrm{CBD}$ indicated non-activation of neuroreceptors CB1 and CB2 and demonstrated a good interaction with 
the 5-hydroxytryptamine-1A (5-HT1A) neuro-receptor [29]. However, recent findings have clearly shown that CBD is an effective drug for Panic Disorder (PD) treatment, both in animal models and in healthy volunteers. Therefore, it is a need for further research on determining the mechanism for CBD's action and the safe and optimal doses of the compound [26].

Urena lobata L. (Family: Malvaceae), a shrubby herb widely distributed annually throughout the world, including Africa, Asia, and South America [4]. U. lobata is commonly used in the treatment of diabetes, gonorrhea, malaria, dysentery, abdominal colic, nausea, rheumatism, and edema in folk medicines [27, 31]. Scientific reports indicate that the plant has anti-bacterial, antihyperglycemic, anti-nociceptive, anti-diarrheal, antiinflammatory, and wound healing activities $[8,22,28]$. A recent study suggests that compounds from $U$. lobata can inhibit nitric oxide production in lipopolysaccharide-induced RAW264.7 macrophage cells [20]. In China, $U$. lobata is clinically used to treat pathological leucorrhea and gonorrhea [23]. To date, a number of bioactive constituents have been isolated from this medicinal herb; these include flavonoids, phenylethyl glycosides, lignans, coumarins, triglycerides [14, $20,25,35,37$, megastigmane glycosides [36], urenalignosides A-D, and lignins [20].

This study aims to examine the anxiolytic-like effect of the methanol bark aerial parts extract of $U$. lobata in Swiss mice.

\section{Materials and methods}

Collection, identification, and extraction of plant materials The aerial parts of $U$. lobata were obtained during December from the Chittagong Hill Tracts. Taxonomist, Bangladesh Forest Research Institute (BFRI), Chittagong, Bangladesh, identified the plant. There has been a collection of valuables (BFRIH-7011).

The plant materials were dried (temperature not exceeding $45{ }^{\circ} \mathrm{C}$ ) and made into a coarse powder using a suitable grinder. Approximately $250 \mathrm{gm}$ powdered materials were soaked into $1.2 \mathrm{~L}$ absolute methanol with occasionally manual stirring for 14 days. Then the soaked materials were filtered through a surgical cotton plug and followed by filtration through Whatman filter paper No. 1 grade. The solvent was evaporated by using a rotary evaporator. The yield value was $9.11 \%$.

\section{Drugs and chemicals}

Diazepam (DZP, Square Pharmaceuticals Ltd.) was used as a standard drug. Tween 80 and all the other reagents and chemicals were purchased from Sigma-Aldrich, Denmark.

\section{Phytochemical investigations}

The methanol extract of the plant was screened for various phytoconstituents according to the procedure described by Khandelwal [18].

\section{Experimental animals}

Swiss albino male mice (22-28 g) were obtained from the animal house facilities of the Bangladesh Council for Scientific \& Industrial Research (BCSIR), Chittagong, Bangladesh. The animals were free to access food and water ad libitum and were housed in polypropylene cages at a temperature $\left(25 \pm 1{ }^{\circ} \mathrm{C}\right)$ throughout the study. The experiments were conducted from 9.00 am to 2.00 $\mathrm{pm}$. After the examination, all animals were euthanized with sodium pentobarbital (135 $\mathrm{mg} / \mathrm{kg}$, i.p.) and were sacrificed. The experimental protocol was approved (\#SUB-TI-14) by the Department of Pharmacy, Southern University Bangladesh (SUB), Chittagong, Bangladesh.

\section{Acute toxicity study}

We followed the OECD guidelines for this test. Albino mice $(n=6)$ were randomly selected in this study. The animals fasted only with free access to the water for 12 hours. The animals were then weighed and orally tested at 1000, 2000, 3000, and $4000 \mathrm{mg} / \mathrm{kg}$ for extract. Then the animals had been deprived of their food for 2 hours and the first four hours afterward for 72 hours, and afterward for 7 days after administration of the drugs, mortality and clinical signs (e.g., skin, fur, eyes, and mucosal signs) were noted. Gross conduct such as body position, locomotion, raising, tremors, and gait have been observed for seven days. The impact of plant extracts on the grip strength, pain response, and an accurate reflection has been recorded. Therefore, food and water consumption are tracked.

\section{Test for anxiolytic-like effects}

\section{Experimental design}

To study the anxiolytic effect of MEUL, thirty-five mice were randomly divided into seven groups of five animals each $(n=5)$. Group I: Negative control (vehicle: $0.05 \%$ tween 80 dissolved in $0.9 \% \mathrm{NaCl}$ solution); group II: Positive control (DZP); groups III and IV were treated with MEUL: 250 and $500 \mathrm{mg} / \mathrm{kg}$ ), respectively; groups $\mathrm{V}$ and VI were treated with a combination of DZP2 and MEUL (DZP2 + MEUL 250 and DZP2 + MEUL 500).

\section{Open-field test (OFT)}

This test was performed according to a published procedure with slight modification [3]. According to this procedure, animals received controls and test extract 30 min before the test. Then the animals were individually placed in the center of the box and allowed to move freely. The number of squares crossed with all four 
paws, rearings, and a number of grooming were recorded for $3 \mathrm{~min}$ (testing period). In the combined treatment groups, DZP (2 mg/kg, i.p.) was given $15 \mathrm{~min}$ before MEUL administration, and parameters mentioned earlier were similarly recorded.

\section{Light-dark test (LDT)}

After $30 \mathrm{~min}$ of administration of controls and test samples, mice were placed in the middle of the light compartment. The animals were then observed for 3 min, and the time spent inside the dark box was recorded [15]. In the combined treatment groups, DZP (2 $\mathrm{mg} / \mathrm{kg}$, i.p.) was administered $15 \mathrm{~min}$ before the MEUL administration, and the above-mentioned parameter was similarly recorded.

\section{Swing test (SWT)}

In this test, the number of swings of each animal was recorded for $3 \mathrm{~min}$, after $30 \mathrm{~min}$ of administration of controls and MEUL [17]. In the combined treatment groups, DZP (2 mg/kg, i.p.) was given $15 \mathrm{~min}$ before the MEUL administration, and a number of swings were recorded similarly.

\section{Statistical analysis}

Results are expressed as the mean \pm standard error of the mean (SEM). Data were analyzed by one-way analysis of variance (ANOVA) Neuman Keul's test using Graph Pad Prism (version: 6.0) software, considering $p \leq$ 0.05 at $95 \%$ confidence intervals.

\section{Results}

The phytochemical reports suggest that the plant contains alkaloids, glycosides, flavonoids, terpenes, saponins, gums, and reducing sugars (Table 1 ).

The MEUL (1000, 2000, 3000, and $4000 \mathrm{mg} / \mathrm{kg}$, p.o.) did not change the frequently observed parameters (e.g., writing, grooming, corneal reflex, touch response, torch response, pain response, tremors, convulsion, righting reflux, skin color,pinna reflex, restlessness, alertness, pupils, urination, food intake, gripping, lacrimation, salivation, and water intake) in the experimental animals (Table 2). The extract did not exert toxic or lethal effects, suggesting the median lethal dose $\left(L D_{50}\right)$ of the extract might be more significant than $4000 \mathrm{mg} / \mathrm{kg}$ (p.o.).

Shown in Table 3 are the results of our investigation pertaining to the anxiolytic-like effects of the MEUL. Results reveal that DZP $(2 \mathrm{mg} / \mathrm{kg})$ significantly $(p<0.05)$ reduced the number of field cross, rearing, and grooming in OFT. DZP also decreased the light residence time and number of swings in experimental animals in comparison to the NC and MEUL groups. MEUL dose-dependently exerted a calming effect in experimental
Table 1 Phytochemical relevance of the methanolic crude extract of U. lobata

\begin{tabular}{ll}
\hline Phytochemical groups & Test results \\
\hline Alkaloids & ++ \\
Glycosides & +++ \\
Flavonoids & +++ \\
Terpenoids & +++ \\
Steroids & ++ \\
Tannins & - \\
Saponins & ++ \\
Gums & + \\
Reducing Sugars & + \\
\hline
\end{tabular}

Intensity: $(-) \rightarrow$ No, $(+) \rightarrow$ Low,$(++) \rightarrow$ Moderate, $(+++) \rightarrow$ Strong

animals. MEUL at $500 \mathrm{mg} / \mathrm{kg}$ significantly reduced the number of square crossing, rearing, and grooming parameters in OFT. MEUL at $500 \mathrm{mg} / \mathrm{kg}$ also significantly increased the light residence time and number of swings in Swiss mice.

Moreover, MEUL (250 and $500 \mathrm{mg} / \mathrm{kg}$ ), co-treated with the DZP $(2 \mathrm{mg} / \mathrm{kg}$, i.p.) group, caused an anxiolytic-like effect through modifying the test parameters in OFT, LDT, and SWT. In this case, the MEUL at $500 \mathrm{mg} / \mathrm{kg}$ showed better activity than its $250 \mathrm{mg} / \mathrm{kg}$ counterpart (Table 4).

\section{Discussion}

Medicinal plants' usage plays a crucial role in the complementary and alternative medicine system and has been acquired much interest in developed countries. Acute toxicity study followed by OECD guidelines helps us determine a safe dose of any substance (e.g., crude extracts, isolated compounds, food additives, chemical ingredients using laboratory animals (e.g., rats, mice, rabbits). The World Health Organization (WHO) reports that medicinal plants have been a unique ingredient in modern medicine since ancient times. However, it is important to know the appropriate and safe dose in a human before starting treatment with them [2]. We can confirm that using different animals in the laboratory in the method of acute oral toxicity analysis. In our study, MEUL did not show poisoning effects on the Swiss mice up to $4000 \mathrm{mg} / \mathrm{kg}$ oral dose; therefore, this dose may be considered for this category of the experimental animal.

Anxiety is a common issue at present, especially since the novel coronavirus disease (Covid-19) pandemic has increased its levels one step further worldwide [24, 39]. So far, several psychiatric drugs are being used to treat anxiety. Unfortunately, these drugs have many side effects. However, we can use herbal medicines to approach 
Table 2 Effect of methanolic extract of U. lobata on acute oral toxicity test in Swiss albino mice

\begin{tabular}{|c|c|c|c|c|c|}
\hline \multirow{2}{*}{$\begin{array}{l}\text { Observed } \\
\text { parameters }\end{array}$} & \multicolumn{5}{|c|}{ Responses } \\
\hline & $0 \mathrm{mg} / \mathrm{kg}$ & $1000 \mathrm{mg} / \mathrm{kg}$ & $2000 \mathrm{mg} / \mathrm{kg}$ & $3000 \mathrm{mg} / \mathrm{kg}$ & $4000 \mathrm{mg} / \mathrm{kg}$ \\
\hline Alertness & N & N & N & N & N \\
\hline Grooming & A & A & A & A & A \\
\hline Restlessness & A & A & $A$ & A & A \\
\hline Touch response & $\mathrm{N}$ & $\mathrm{N}$ & N & N & $N$ \\
\hline Torch response & $\mathrm{N}$ & N & $\mathrm{N}$ & $\mathrm{N}$ & N \\
\hline Pain response & $\mathrm{N}$ & $\mathrm{N}$ & $\mathrm{N}$ & No & N \\
\hline Tremors & A & A & A & A & A \\
\hline Convulsion & A & $A$ & $A$ & A & A \\
\hline Righting reflux & $\mathrm{N}$ & N & $N$ & $N$ & N \\
\hline Gripping & N & N & N & N & N \\
\hline Pinna reflex & $P$ & $P$ & $P$ & $P$ & $P$ \\
\hline Corneal reflex & $P$ & P & $P$ & $P$ & $P$ \\
\hline Writhing & A & A & $A$ & $A$ & $A$ \\
\hline Pupils & N & N & N & N & N \\
\hline Urination & $\mathrm{N}$ & $\mathrm{N}$ & $\mathrm{N}$ & $\mathrm{N}$ & $\mathrm{N}$ \\
\hline Salivation & N & N & N & $N$ & N \\
\hline Skin color & $\mathrm{N}$ & $N$ & $\mathrm{~N}$ & N & $\mathrm{N}$ \\
\hline Lacrimation & N & N & N & N & N \\
\hline Food intake & $N$ & $\mathrm{~N}$ & $N$ & N & N \\
\hline Water intake & N & N & $N$ & $N$ & $N$ \\
\hline Mortality & - & - & - & - & - \\
\hline
\end{tabular}

$N$ Normal, $A$ Absent, $P$ Present, (-) - Nil

this disease $[5,10]$. So focusing on traditional herbal medicine is a common fashion nowadays [38]. For example, compounds derived from medicinal plants have immunomodulatory effects; people have been using them safely since ancient times [19]. U. lobata has various important biological activities, including antioxidant and neuropharmacological effects [17]. Based on the above scientific, we have evaluated its anxiolytic effect in Swiss mice taking a popularly used standard anxiolytic drug DZP.

Anxiety is caused by an animal's isolation and agoraphobia from its social community [1]. In the OFT, locomotion declines (diminished exploration), often involving anxieties, were found. In this study,
MEUL was found to modulate OFT and SWT parameters, along with an increase in light residence time of experimental animals.

BDZs (e.g., DZP) are positive allosteric modulators of the $\mathrm{GABA}_{\mathrm{A}}$. GABA is the most critical inhibitor of the brain that increases chloride ion conductivity through neuronal cells' membrane following binding to BDZs. It triggers the influx of chloride ions to hyperpolarize the neurons' membrane potential, which increases the difference between rest and threshold potential, thereby lowering nerve firing. Therefore, arousal of the cortical and limbic systems is decreased in the CNS [30]. To exert a calming effect, DZP

Table 3 Effects of test sample and controls on mice

\begin{tabular}{|c|c|c|c|c|c|c|}
\hline \multirow[t]{2}{*}{ Treatment groups } & & \multicolumn{3}{|c|}{ Open-field test ( $3 \mathrm{~min}$ ) } & \multirow{2}{*}{$\begin{array}{l}\text { Light-dark test ( } 3 \mathrm{~min}) \\
\text { Residence in light }(\mathrm{Sec})\end{array}$} & \multirow{2}{*}{$\begin{array}{l}\text { Swing test ( } 3 \mathrm{~min} \\
\text { Number of swings }\end{array}$} \\
\hline & & Field cross & Rearing & Grooming & & \\
\hline NC (10 mL/kg, p.o.) & & $35.22 \pm 0.87$ & $7.08 \pm 1.13$ & $9.03 \pm 1.25$ & $153.13 \pm 2.17$ & $37.25 \pm 2.19$ \\
\hline DZP (2 mg/kg, i.p.) & & $17.05 \pm 1.46^{*}$ & $3.57 \pm 0.64^{*}$ & $4.41 \pm 0.56^{*}$ & $56.12 \pm 2.97^{*}$ & $9.33 \pm 1.29^{*}$ \\
\hline \multirow[t]{2}{*}{ MEUL (mg/kg, p.o.) } & 250 & $22.64 \pm 1.75^{*}$ & $4.13 \pm 1.28^{*}$ & $4.32 \pm 1.64^{*}$ & $127.65 \pm 2.87^{*}$ & $31.54 \pm 2.63^{*}$ \\
\hline & 500 & $19.75 \pm 2.61^{*}$ & $4.11 \pm 2.03^{*}$ & $4.21 \pm 1.29^{*}$ & $153.02 \pm 2.43$ & $21.12 \pm 2.43^{*}$ \\
\hline
\end{tabular}

Values are the mean \pm SEM $(n=5)$. ANOVA followed by Neuman Keuls test, ${ }^{*} p<0.05$ when compared to NC group. NC Negative control (Vehicle: $0.05 \%$ tween 80 dissolved in $0.9 \% \mathrm{NaCl}$ solution), DZP Diazepam, MEUL Methanol extract of U. lobata 
Table 4 Combined effects of the test sample and DZP in Swiss mice

\begin{tabular}{|c|c|c|c|c|c|}
\hline \multirow[t]{2}{*}{ Treatment groups } & \multicolumn{3}{|c|}{ Open-field test ( $3 \mathrm{~min}$ ) } & \multirow{2}{*}{$\begin{array}{l}\text { Light-dark test ( } 3 \mathrm{~min} \text { ) } \\
\text { Residence in light (Sec) }\end{array}$} & \multirow{2}{*}{$\begin{array}{l}\text { Swing test ( } 3 \mathrm{~min} \text { ) } \\
\text { Number of swings }\end{array}$} \\
\hline & Field cross & Rearing & Grooming & & \\
\hline NC (10 mL/kg, p.o.) & $35.22 \pm 0.87$ & $7.08 \pm 1.13$ & $9.03 \pm 1.25$ & $153.13 \pm 2.17$ & $37.25 \pm 2.19$ \\
\hline DZP & $17.05 \pm 1.46^{*}$ & $3.57 \pm 0.64^{*}$ & $4.41 \pm 0.56^{*}$ & $56.12 \pm 2.97^{*}$ & $9.33 \pm 1.29^{*}$ \\
\hline DZP2 + MEUL250 & $19.04 \pm 2.03^{* \#}$ & $3.39 \pm 0.24^{*}$ & $4.01 \pm 1.67^{*}$ & $141.61 \pm 3.07^{* \#}$ & $28.13 \pm 1.03^{* \#}$ \\
\hline DZP2 + MEUL500 & $23.05 \pm 2.68^{* \#}$ & $3.19 \pm 1.07^{* \#}$ & $3.04 \pm 2.13^{* \#}$ & $151.11 \pm 2.39^{* \#}$ & $34.01 \pm 2.03^{* \#}$ \\
\hline
\end{tabular}

Values are the mean \pm SEM $(n=5)$. ANOVA followed by NeumanKeuls test, ${ }^{*} p<0.05$ when compared to the NC group. NC: Negative control (Vehicle: $0.05 \%$ tween 80 dissolved in $0.9 \% \mathrm{NaCl}$ solution). ${ }^{\#} p<0.05$ when compared to the positive control (DZP) group. DZP Diazepam, MEUL Methanol extract of $U$. Iobata

appears to act on areas of the limbic system, thalamus, and hypothalamus. In this context, our results show that MEUL at a dose of $500 \mathrm{mg} / \mathrm{kg}$ may elicit a better calming effect on the experimental animals. This effect may be confirmed by reducing the movement of animals in the open-field and swing boxes and time spent in the light chamber of the dardlightbox. Moreover, the MEUL was also found to modulate the calming effect of DZP in experimental animals, where the extract at both doses plus $2 \mathrm{mg} /$ $\mathrm{kg}$ of DZP groups showed better anxiolytic-like effects than the individually treated groups with MEUL or DZP.

Researches have demonstrated that plant extracts containing a wide range of phytochemicals, including alkaloids, glycosides, terpenes, flavonoids, phenolic acids, lignans, cinnamates, and saponins, may exert anxiolyticlike effects in animal models [11]. Our findings demonstrated that MEUL contains alkaloids, glycosides, flavonoids, phenols, saponins, and terpenes.

\section{Conclusions}

MEUL contains important plant secondary metabolites, including alkaloids, glycosides, flavonoids, and terpenes. The extract exhibited a calming effect in Swiss mice in a dose-dependent manner and modulated the standard drug's anxiolytic effects, DZP. The extract was found to potentiate the anxiolytic-like effect of DZP. Further studies are required to isolate the plant's responsible, active constituents and understand the possible mechanism of action behind the anxiolytic-like effect in experimental animals. Other studies are needed to determine the safety, effectiveness, and active components of this plant.

\section{Abbreviations \\ 5-HT1A: 5-Hydroxytryptamine-1A; BDZs: Benzodiazepines; CBD: Cannabidiol; CNS: Central nervous system; DZP: Diazepam; GABA: Gamma-aminobutyric acid; MEUL: Methanolic extract of Urena lobata}

\section{Acknowledgements}

The author is owed to the Department of Pharmacy, Southern University Bangladesh, for providing laboratory supports for this study.

\section{Competing interest}

None declared.

\section{Author details}

${ }^{1}$ Department of Pharmacy, Life Science Faculty, Bangabandhu Sheikh Mujibur Rahman Science and Technology University, Gopalganj (Dhaka) 8100, Bangladesh. ${ }^{2}$ Department of Pharmacology, School of Medicine, Institute of New Drug Development, Jeonbuk National University, Jeonju 54907, South Korea. ${ }^{3}$ Phytochemistry Research Center, Shahid Beheshti University of Medical Sciences, Tehran, Iran. ${ }^{4}$ Department of Pharmacognosy and Biotechnology, School of Pharmacy, Shahid Beheshti University of Medical Sciences, Tehran, Iran. ${ }^{5}$ Facultad de Medicina, Universidad del Azuay, Cuenca, Ecuador.

Received: 18 July 2020 Accepted: 11 January 2021

Published online: 20 January 2021

\section{References}

1. Ambavade S, Mhetre N, Tate V, Bodhankar S. "Pharmacological evaluation of the extracts of Sphaeranthus indicus flowers on anxiolytic activity in mice.". Indian Journal of Pharmacology. 2006:38(4):254.

2. Antman EM. (2008). "ST-elevation myocardial infarction: pathology, pathophysiology, and clinical features." Heart disease: 1207-1232.

3. Archer J. Tests for emotionality in rats and mice: a review. Animal behaviour. 1973;21(2):205-35

4. Babu SS, Madhuri DB, Ali SL. "A pharmacological review of Urena lobata plant." Asian. J Pharm Clin Res. 2016;9(2):20-2.

5. Calixto J. "Efficacy, safety, quality control, marketing and regulatory guidelines for herbal medicines (phytotherapeutic agents).". Brazilian Journal of medical Biological research. 2000;33(2):179-89.

6. Chew AL, Jessica JJA, Sasidharan S. "Antioxidant and antibacterial activity of different parts of Leucas aspera.". Asian Pacific Journal of Tropical Biomedicine. 2012;2(3):176-80.

7. Danon JJ, Reekie TA, Kassiou M. Challenges and opportunities in central nervous system drug discovery. Trends in Chemistry. 2019;1(6):612-24.

8. De las Heras B, Slowing K, Benedı J, Carretero E, Ortega T, Toledo C, Bermejo P, Iglesias I, Abad M, Gómez-Serranillos P. Antiinflammatory and antioxidant activity of plants used in traditional medicine in Ecuador. J Ethnopharmacol. 1998;61(2):161-6.

9. Essig CF. Addiction to nonbarbiturate sedative and tranquilizing drugs. Clin Pharmacol Ther. 1964;5(3):334-43.

10. Fajemiroye JO, da Silva DM, de Oliveira DR, Costa EA. Treatment of anxiety and depression: medicinal plants in retrospect. Fundam Clin Pharmacol. 2016;30(3):198-215.

11. Fedotova J, Kubatka P, Büsselberg D, Shleikin AG, Caprnda M, Dragasek J, Rodrigo L, Pohanka M, Gasparova I, Nosal V. Therapeutical strategies for anxiety and anxiety-like disorders using plant-derived natural compounds and plant extracts. Biomed Pharmacother. 2017;95:437-46.

12. Fishbain DA, Rosomoff HL, Rosomoff RS. Drug abuse, dependence, and addiction in chronic pain patients. Clin J Pain. 1992;8(2):77-85.

13. Foreman JC, Johansen T, Gibb AJ. (2011). Textbook of receptor pharmacology, CRC press.

14. Gao X-L, Liao Y, Wang J, Liu X-Y, Zhong K, Huang Y-N, Gao H, Gao B, Xu Z-J. "Discovery of a potent anti-yeast triterpenoid saponin, clematoside-S from Urena lobata L.". Int J Mol Sci. 2015;16(3):4731-43.

15. HascoëT M, Bourin M. A new approach to the light/dark test procedure in mice. Pharmacology Biochemistry Behavior. 1998;60(3):645-53. 
16. Isbell $\mathrm{H}$, Fraser $\mathrm{H}$. "Addiction to analgesics and barbiturates.". Pharmacol Rev. 1950;2(2):355-97.

17. Islam MT, Freitas R, Oliveira G, Guha B. "Neuropharmacological screenings of hydroalcoholic fractions of Urena lobata L.". World J Pharm Pharmaceut Sci. 2014;3:62-71.

18. Khandelwal KR. (2008). Practical pharmacognosy, Pragati Books Pvt. Ltd.

19. Licciardi PV, Underwood JR. "Plant-derived medicines: a novel class of immunological adjuvants. " International immunopharmacology. 2011;11(3): 390-8.

20. Luo Y, Su C, Ding N, Qi B, Jia F, Xu X, Liu X, Wang J, Wang X, Tu P. "Lignan Glycosides from Urena lobata" Molecules. 2019;24(15):2850.

21. Luvah M, Ochieng GCO, Manguro LOA, Owuor PO, Ishola IO. "Anxiolytic-like effect of underground parts of Ajuga remota Benth (Lamiaceae) and its bioactive constituents in mice: A behavioral study.". The Natural Products Journal. 2014;4(3):211-6.

22. Mazumder U, Gupta M, Manikandan L, Bhattacharya S. Antibacterial activity of Urena lobata root. Fitoterapia. 2001;72(8):927-9.

23. Medicine AE. C. o. t. A. B. o. T. C. (1999). Chinese Materia Medica (Zhonghua Bencao), Shanghai Science \& Technology Press Shanghai.

24. Menzies RE, Menzies RG. (2020). "Death anxiety in the time of COVID-19: Theoretical explanations and clinical implications." The Cognitive Behaviour Therapist 13.

25. Morelli CF, Cairoli P, Speranza G, Alamgir M, Rajia S. "Triglycerides from Urena lobata" Fitoterapia. 2006;77(4):296-9.

26. Soares $P, V$. and Campos AC. Evidences for the anti-panic actions of cannabidiol. Current neuropharmacology. 2017:15(2):291-9.

27. Pharmacopoeia C. Commission. Pharmacopoeia of the People's Republic of China. Beijing: China Medical Science Press; 2010.

28. Pieme C, Penlap V, Ngogang J, Costache M. In vitro cytotoxicity and antioxidant activities of five medicinal plants of Malvaceae family from Cameroon. Environmental toxicology pharmacology. 2010;29(3):223-8.

29. de Mello Schier R, de Oliveira Ribeiro ANP, Coutinho DS, Machado S, AriasCarrión O, Crippa JA, Zuardi AW, Nardi AE, Silva AC. "Antidepressant-like and anxiolytic-like effects of cannabidiol: a chemical compound of Cannabis sativa." CNS \& Neurological Disorders-Drug Targets (Formerly Current Drug Targets-CNS \&. Neurological Disorders). 2014;13(6):953-60.

30. Ries RK, Miller SC, Fiellin DA. (2009). Principles of addiction medicine, Lippincott Williams \& Wilkins.

31. Sajem AL, Gosai K. Traditional use of medicinal plants by the Jaintia tribes in North Cachar Hills district of Assam, northeast India. J Ethnobiol Ethnomed. 2006;2(1):33.

32. Sarris J, Byrne GJ, Cribb L, Oliver G, Murphy J, Macdonald P, Nazareth S, Karamacoska D, Galea S, Short A, Ee C, Birling Y, Menon R, Ng CH. "Ltheanine in the adjunctive treatment of generalized anxiety disorder: A double-blind, randomised, placebo-controlled trial.". J Psychiatr Res. 2019; 110:31-7.

33. Schuckit MA. (1994). "Low level of response to alcohol as a predictor of future alcoholism." The American journal of psychiatry.

34. Seldenrijk A, Vis R, Henstra M, Ho PK, van Grootheest D, Salomons T, Overmeire F, de Boer M, Scheers T, Doornebal-Bakker R. "Systematic review of the side effects of benzodiazepines" Nederlands tijdschrift voor geneeskunde. 2017;161:D1052.

35. Shi X, Su C, Qi B, Yang W, Wu Y, Ding N, Dong X, Shi S. "Flavonoid glycosides from Aerial part of Urena lobate." Chin. Pharm J. 2017;52:19-23.

36. Su C, Qi B, Wang J, Ding N, Wu Y, Shi X-P, Zhu Z-X, Liu X, Wang X-H, Zheng J. "Megastigmane glycosides from Urena lobata" Fitoterapia. 2018;127:123-8.

37. Su C, Yang W, Jiang D, Zhang X, Zheng J, Shi S, Tu P. Flavonoids from Urena lobata. Chin Tradit Herbal Drugs. 2015;46:2034-9.

38. Uddin MJ, Zidorn C. (2020). "Traditional Herbal Medicines Against CNS Disorders from Bangladesh." Natural Products and Bioprospecting: 1-33.

39. Vellingiri B, Jayaramayya K, lyer M, Narayanasamy A, Govindasamy V Giridharan B, Ganesan S, Venugopal A, Venkatesan D, Ganesan H. (2020). "COVID-19: A promising cure for the global panic." Science of The Total Environment: 138277.

\section{Publisher's Note}

Springer Nature remains neutral with regard to jurisdictional claims in published maps and institutional affiliations.

\section{Submit your manuscript to a SpringerOpen ${ }^{\circ}$ journal and benefit from:}

- Convenient online submission

- Rigorous peer review

- Open access: articles freely available online

High visibility within the field

- Retaining the copyright to your article

Submit your next manuscript at $\boldsymbol{\triangleright}$ springeropen.com 